UDC 821.161.1.09 Puškin A. S.

https://doi.org/10.18485/ms_zmss.2021.99.18

\author{
Мария Александрова \\ Нижегородский государственный \\ лингвистический университет им. Н. А. Добролюбова, \\ Международная научно-исследовательская лаборатория \\ «Фундаментальные и прикладные исследования \\ аспектов культурной идентификации» \\ nam-s-toboi@mail.ru
}

Maria Aleksandrova

Linguistics University of Nizhny Novgorod

The International Research Laboratory

of Basic and Applied Aspects of Cultural Identification

nam-s-toboi@mail.ru

\title{
МИФЫ О ПУШКИНЕ И СТИХОТВОРЕНИЕ БУЛАТА ОКУДЖАВЫ «СЧАСТЛИВЧИК»
}

\section{PUSHKIN'S MYTHS AND BULAT OKUDZHAVA'S POEM "LUCKY MAN"}

Стихотворение Булата Окуджавы рассмотрено: в свете общекультурных закономерностей, определяющих воссоздание образа великого поэта; на фоне основных тенденций мифологизации Пушкина в литературе советской эпохи; в контексте разных представлений о поэтическом даре. При реконструкции творческой истории «Счастливчика» особое внимание уделено рецепции пушкинианы Булгакова. Показана взаимосвязь речевой композиции стихотворения и структуры образа счастливчика. Целостная интерпретация судьбы Пушкина в стихотворении Окуджавы осмыслена как лирический миф, правдивость которого была по достоинству оценена Ю. М. Лотманом.

Ключевые слова: Пушкин, Окуджава, Булгаков, миф, диалог, подтекст.

Bulat Okudzhava's poem is examined from several perspectives: the cultural tendencies determining the reconstruction of the image of the poet, the ideological context regarding the concept of the poetic gift, and Pushkin's myth in the literature of the Soviet era. We analyze the reception of Bulgakov's Pushkiniana and show the relationship between the composition of the poem under analysis and the structure of the image of the lucky man. Okudzhava's interpretation of Pushkin's fate, appreciated for its authenticity by Yu. M. Lotman, is viewed as a lyrical myth.

Keywords: Pushkin, Okudzhava, Bulgakov, myth, dialogue, subtext.

1 Статья существенно уточняет и развивает идеи, впервые высказанные автором в публикации: Александрова М. А. «Стихотворение Булата Окуджавы “Счастливчик Пушкин” в системе контекстов». Болдинские чтения. Нижний Новгород: Издательство Нижегородского госуниверситета, 2019: 163-174. 


\section{1. Образ поэта как «творимая легенда»}

Общепризнано, что представление о личности поэта формируется и живёт в культуре по мифоподобным законам. Лирическая личность потенциально мифологична в силу того, что «принадлежит одновременно и миру действительности, и миру воображения. <...> Лирик - лицо не просто пишущее, но и действующее, живущее бурной и самостоятельной жизнью героя, а не отвлечённо-кабинетной жизнью автора»; зачастую поэт сам себе мифотворец, инициатор «творимой легенды», которую подхватывают современники и наследуют потомки (Эпштейн 1988: 104). В большом историческом времени миф о поэте существует на основе «национальной памяти, дополненной идеализирующим воображением», и «чем крупнее поэтическая судьба, тем менее принадлежит она одной лишь истории, тем более универсальный и символический образ её складывается в сознании народа» (Эпштейн 1988: 103, 104).

Лирик, создающий образ лирика, творит своего рода двойной миф, в котором максимально раскрывается его собственная личность, поверяется её масштаб. Творческий случай Окуджавы необычен в первую очередь отношением к важнейшему моменту мифа (мифов) о поэтах русского «золотого века» - интерпретации их гибели.

Ещё во второй половине XIX в. сложилась и в начале XX в. упрочилась традиция писательских юбилеев, приуроченных к годовщине смерти: «Смерть литератора в русской культуре окружена мученическим ореолом», наделена «огромным символическим и риторическим потенциалом» (Вдовин 2010: 84). Досоветский опыт обобщил в своё время А. Ф. Кони: «Смерть гораздо сильнее ударяет по сердцам, чем рождение», поэтому «нужно праздновать именно день смерти Пушкина, <... и праздновать в том смысле, что с этого момента началось настоящее рождение русской литературы» (Кони 1968: 73). В советский период исчезли сами основания для рефлексии об уместности праздновать «юбилей смерти» (Вдовин 2010: 90). Поколению Окуджавы (чьи школьные и университетские годы совпали с первыми этапами советской канонизации русских классиков) была памятна риторика 1930-1940-х гг., когда трагедия «мученика» символически разрешалась актом народного мщения: «Мы твоих убийц не позабыли: // в зимний день, под заревом небес, // мы царю России возвратили// пулю, что послал в тебя Дантес» (Смеляков 1967: 191).

Если официальный миф о Пушкине был монолитен, однообразен, то неподцензурная словесность отразила его во множестве «зеркал». Пропагандистский сюжет «если бы Пушкин жил в наше время» обыгран в анекдотах из серии «Пушкин на приёме у Сталина»: по завершении беседы «лучший друг писателей» вызывает «товарища Дантеса» для выполнения ответственного задания (Архипова 2011: 184-190). «Пушкинские» анекдоты Даниила Хармса обнажали абсурдность самих прин- 
ципов, на которых было построено продвижение классика «в массы»: «Хармс <...> не измишља тек историјску грађу, већ пародира оно што стоји изван текста - бољшевички култ Пушкина» (Поповић 2019: 178). Булгаков в знаменитом эпизоде Macmepa u Maргарить показал Пушкина глазами литературной посредственности, размножившейся благодаря «формовке советского писателя» (Е. Добренко): «Вот пример настоящей удачливости... <...> Какой бы шаг он ни сделал в жизни, что бы ни случилось с ним, всё шло ему на пользу, всё обращалось к его славе! Но что он сделал? Я не постигаю... Что-нибудь особенное есть в этих словах: “Буря мглою...”? Не понимаю!.. Повезло, повезло! - вдруг ядовито заключил Рюхин < ..>, - стрелял, стрелял в него этот белогвардеец и раздробил бедро и обеспечил бессмертие...»² (Булгаков 1966: 48).

Приход булгаковского романа к читателю знаменательно совпал с тем временем, когда официальная доктрина окончательно самопародировалась, а «пушкинский вопрос» стал главным в рефлексии о вечных ценностях. Размежевание с официозом было отправной точкой для разных творческих стратегий. Поиск универсального смысла страданий и смерти художника закономерно приводил к мифу о «священной жертве», к пушкинскому «Пророку», воспринятому в свете речи Александра Блока «О назначении поэта». Вдохновлённый недосягаемым идеалом, Александр Галич испытывал к страдальцам «не жалость, не сочувствие, а зависть» (Новиков 2006: 470). С другой стороны, превращение пушкинского времени в альтернативу современности, актуализация мифа о русском «золотом веке» делало фигуру поэта «метафорой» своего века - «гармоничного и целостного» (Захарченко 2004: 146). В ностальгическом контексте смерть поэта тоже трактовалась универсально - как неизбежная кратковечность лучшего: «Счастливый Пушкин! век твой зыбкой,//Век балов, баловней, карет, //Казалось, жизни знал секрет, // О чём твой стих поёт с улыбкой» (Сапгир 1992: 68). Счастливый Пушкин оказывался жертвой сверхличных закономерностей - смены лучших времён худшими. Ни ту ни другую позицию Окуджава не разделял.

На фоне творчества современников, для которых «“дар” и “жертва" - не просто тематические мотивы, но категории поэтического мышления» (Новиков 2006: 467), лирический мир Окуджавы предстаёт как «дароцентричный»: доминантой судьбы поэта в его трактовке неизменно становится «полнокровная жизнь, жизнь как дар»; создаётся «сложное катартическое ощущение ценности поэтического дара $<. .>$ и ценности прожитой <поэтом> жизни» (Новиков 2006: 471). Главный исток своего мировидения Окуджава назвал сам: «Творчество Пушкина не просто оказало на меня влияние - оно меня создало» (Окуджава 1987: 28).

Стремясь приблизиться к этой «колоссальной личности» (Окуджава 1997: 18) в своей пушкиниане, поэт избегал стилизации «старины»,

2 Курсив в цитатах здесь и далее мой $-M . A$. 
его мышление оставалось современным. Именно диалог «несовпадающих сознаний» является условием «эстетического события» (Бахтин 1979: 22), и «пушкинское наследие - незавершимое целое, эстетическое событие, в котором <...> нужно искать <...> новые ответы» (Попович 2018: 6).

\section{2. Творческая история стихотворения «Счастливчик»}

Предпосылки возникновения художественной идеи «Счастливчика» (1967) освещаются признанием: «Пушкина я по-настоящему открыл для себя поздно, в 40 лет. Хотя читал его с детства и думал, что люблю. Но именно думал. Оказалось, что я его не знал, не понимал, а просто участвовал в общем хоре. А в сорок лет я почувствовал Пушкина и стал перечитывать его другими глазами. Как стихи моего близкого, хорошего знакомого, как стихи дорогого мне человека, чья трагедия аукнулась во мне очень сильно» (Окуджава 1997: 18). Именование героя трагедии счастливчиком - ключевой парадокс стихотворения.

В ряду важных для автора «Счастливчика» литературных впечатлений - булгаковская пушкиниана: пьеса Последние дни, переизданная в 1965-м, Окуджавой процитирована; о романе Мастер и Маргарита, который стал самым ярким культурным событием 1966 г., следует говорить предположительно. Обоснуем возможность связи текстов.

«Счастливчик» не имел песенного варианта, способного мгновенно разойтись в публике, и в то же время его содержание не предполагало цензурных затруднений; естественным было стремление напечатать программное высказывание - результат личного «открытия» Пушкина. К примеру, стихотворение «Александр Сергеич» («Не представляю Пушкина без падающего снега...») Окуджава отдал в июльский номер Юности за 1966 г., игнорируя диссонанс зимней образности и «сезонного» фона публикации, не связывая её с какой-либо пушкинской датой: обнародовать написанное было всего важнее. Поскольку «Счастливчик» не вошёл ни в одну из авторских подборок в периодике 1966-го (в журналах Смена, Юность, альманахе День поэзии, газете Московский комсомолеи за 6 ноября), логично датировать его создание концом года. Стихотворение впервые напечатано в сборнике Март великодушный, который значился в тематическом плане издательства «Советский писатель» на 1967 г. и был отправлен в набор 21 февраля. Автор мог пополнить состав текстов непосредственно перед сдачей рукописи или в ходе работы с редактором ${ }^{3}$, то есть не позднее конца декабря 1966-го. Итак, велика вероятность, что стихотворение появилось на фоне бурного обсуждения публикации Maстера и Mapгapumbl в 11-м номере журнала Москва.

На перекличку «Счастливчика» с монологом Рюхина у памятника Пушкину впервые указал С. А. Кибальник (1989: 22). Действительно,

3 Редактором книги был В. Фогельсон, неизменный доброжелатель Окуджавы. 
в стихотворении Окуджавы опознаётся тот ракурс восприятия гения, который задал Булгаков; лишь в глазах завистника Пушкин мог предстать «везучим», легко скользящим по жизни:

...и всё ему

просто:

жил в Одессе, бывал в Крыму,

ездил в карете,

деньги в долг давали ему

до самой

смерти.

(Окуджава 1967: 109)

Между тем зависть сопутствует и восхищению, и ностальгической идеализации (Александрова 2007: 196-215); к середине 1960-х Окуджаве было известно по крайней мере два лирических признания такого рода: «Зависть» Коржавина (1944) и «Гусарская песня» Галича (1965). Почему же именно булгаковский эпизод имел, по нашему предположению, первостепенное значение? Именно в то время, когда Окуджава отрефлексировал своё участие «в общем хоре», он встретился в романе Булгакова с самой темой мифологизации гения. Здесь амбивалентный образ «“культурного героя”, претворившегося в миф», редуцирован до «знака»: «Пушкин предстаёт как статуя (памятник), портрет, подмосковный город [Пушкино], где, по версии вампира Варенухи, безобразничает пьяный Стёпа Лиходеев <...>, или же как “действующее лицо” фразеологизмов вроде: “А за квартиру Пушкин платить будет?”» (Яблоков 2001: 139-140). Слова «Пушкино», «пушкинский» так настойчиво повторяются в фантастическом рассказе Варенухи и скептических комментариях Римского (Булгаков 1966: 95-96), что Лиходеев, который «сослан» нечистой силой на юг, становится двойником Пушкина в разных его ипостасях - от «мятежного скитальца» до анекдотического пьяницы-бабни$\mathrm{ka}^{4}$. В параллельном существовании и даже переплетении контрастных вариантов пушкинского мифа Булгаков выразил неприятие любого земного суждения о гении - причастнике иных миров (Яблоков 2001). Хотя в журнальной публикации Maстера и Mapгарить нет эпизода с председателем домового комитета, поминающим всуе нечитанного классика, даже сокращённый текст доносит мысль писателя о неуловимой сущности «явления, называемого “Пушкин”» (Яблоков 2001: 140).

В Последних днях образ Пушкина возникает из «мирской молвы», причём на исчерпывающее объяснение судьбы поэта претендует самый ничтожный участник событий, подавший свою реплику под занавес: «Но не было фортуны ему [из-за стихов]. Как ни напишет, мимо попал, не туда, не те, не такие...» (Булгаков 1965: 410). Сентенция мелкого

4 О комбинации в пушкинском мифе этих мотивов см.: (Загидуллина 2001). 
соглядатая о фатальном «невезении» Пушкина и заключение литературной бездарности о пушкинской «удачливости» образуют выразительный контраст, который, по-видимому, стал для Окуджавы творческим стимулом. Кроме того, вопросы негодующего обывателя («Но что он сделал?..») неожиданно оказывались продуктивными - «остранняющими» - в ситуации набравшего инерцию пушкинского культа.

Некоторое сходство литературного фона также могло влиять на рецепцию произведений Булгакова. В период работы над Мастером u Маргаритой произошла канонизация Маяковского в качестве «социалистического Пушкина» (Мусатов 1998: 134); отсюда пародия на лирическую позицию автора «Юбилейного» в эпизоде с памятником (Гаспаров 1993: 34-35). Сами подходы Маяковского и Булгакова к пушкинской теме были несовместимы: в «Юбилейном», где автор-персонаж вступает в фамильярный контакт с Пушкиным, «над мифологизированным, “мёртвым” образом торжествует “подлинный”, “живой” поэт», тогда как булгаковская пушкиниана построена на мнимом согласии с любым мифом - ввиду заведомой невозможности приобщиться к тайне гения (Яблоков 2001: 140). В годы «оттепели» советский классик, воскресший после своей «второй смерти» (Б. Пастернак), предстал, в свою очередь, воскресителем Пушкина. Возобновилась борьба за «живого» поэта в духе Маяковского, но его масштаб не был унаследован. Когда Е Евтушенко изобразил в лице Пушкина «наш идеал раскованности, непринуждённости» (Эпштейн 1988: 101), тот обернулся разгульным персонажем «низового» мифа: «Он перегусарит // всех гусар. <..> Он перецыганит // всех цыган» (Евтушенко 1962: 59). В этих обстоятельствах Окуджавой сделан «выбор Булгакова»: мифу в самых расхожих его проявлениях поэт демонстративно «поддаётся». В то же время он дерзает угадать своего героя - подобно булгаковскому Мастеру ${ }^{5}$, который «по складу характера и по способу творчества - скорее поэт, чем прозаик» (Новиков 2006: 472).

\section{3. «Многоголосое» слово и структура образа счастливчика}

Вынося в заглавие разговорное слово счастливчик, Окуджава сразу отсылает к толкам о пушкинском «превосходстве» и (или) «везении», которые далее подтверждаются рассказчиком. На этом основании стихотворение рассматривалось как «ролевое»: основная часть, выдержанная в духе анекдотов о «гуляке праздном», заключена строфой, вызывающей в памяти читателя «искрящееся житейское веселье самого Пушкина» (Кибальник 1989: 22-23). Согласно другой трактовке, Окуджава выступает одновременно «и как фольклорный автор-простак <...>, и как ироничный и мудрый автор-интеллигент, который иронизирует

5 «О, как я угадал! О, как я все угадал!» (Булгаков 1966: 34). 
прежде всего над собой» (Абельская 2008: 102). К сожалению, мысль об «оксюморонности» авторской позиции не получила развития в этой работе.

Закономерно возникает вопрос об окуджавской рецепции образов и мотивов творчества Пушкина. Венгерский литературовед Нина Секей предварила свой краткий разбор «Счастливчика» упоминанием двух пушкинских текстов - «К портрету Вяземского» (1820) и «Вяземскому» (1821):

Судьба свои дары явить желала в нём, В счастливом баловне соединив ошибкой Богатство, знатный род - с возвышенным умом И простодушие с язвительной улыбкой.

(Пушкин 1956: 15)

\begin{abstract}
Язвительный поэт, остряк замысловатый, И блеском колких слов, и шутками богатый, Счастливый Вяземский, завидую тебе. Ты право получил, благодаря судьбе, Смеяться весело над злобою ревнивой, Невежество разить анафемой игривой.
\end{abstract}

(Пушкин 1956: 91)

Согласно логике Н. Секей, Окуджава словно бы откликается на пушкинскую «зависть», наделяя героя стихотворения тем, «чего так не хватало Пушкину» в реальной жизни; условием счастливого превращения стало переключение внимания на ““лирического героя”, от лица которого ведётся этот своеобразный “сказ”», человека «не очень далёкого, но впрочем и не глупого, скорее маскирующегося под простака»; одним словом, «в этом стихотворении главная фигура не Пушкин» (Секей 1971: 164). Но в таком случае вывод о «серьёзном убеждении» автора стихотворения, что «жизнь Пушкина при всём трагизме была полной, яркой, значительной» (Секей 1971: 164), остаётся общим местом («противоположным общим местом» по отношению к «мирской молве»).

Осмыслить парадоксальный художественный строй «Счастливчика», приблизиться к окуджавской концепции судьбы Пушкина позволит решение двуединой задачи: это «расшифровка» самой интонации поэтического рассказа и установление реальных межтекстовых связей.

В начальном двустишии «Счастливчика» выделены, благодаря «расшатанному» ритму и сильной позиции, эпитеты-наречия, вторящие заглавию:

Александру Сергеичу хорошо!

Ему прекрасно!

В авторском исполнении, сохранённом аудиозаписями разных лет, слова хорошо и прекрасно звучат с выраженным эмфатическим ударением на растянутых гласных; Окуджава как бы заключает фразу в кавычки, 
создавая дистанцию по отношению к тому, кто оценивает счастливчика. Но угол зрения быстро меняется; герой стихотворения сам задаёт тон:

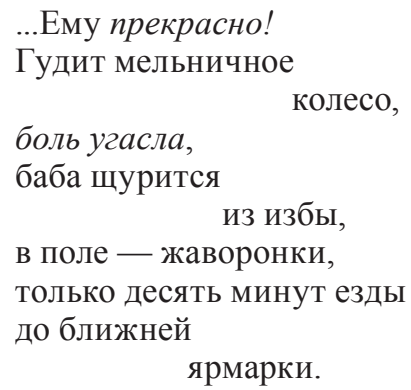

Угасшая боль знаменует «присутствие» Александра Сергеича и объясняет, уже с его собственной точки зрения, в чём заключается провозглашённое ранее хорошо. Так счастливчик становится образом-оксюмороном - и как носитель контрастных состояний (больно / хорошо), и как скрещение разных точек зрения (извне / изнутри).

Упоминание ближней ярмарки мотивирует игру с жанром балаганного представления. Александр Сергеич словно бы выходит на подмостки, действует на виду у публики; простой сюжет - согласно жанровым законам - вмещает целую жизнь:

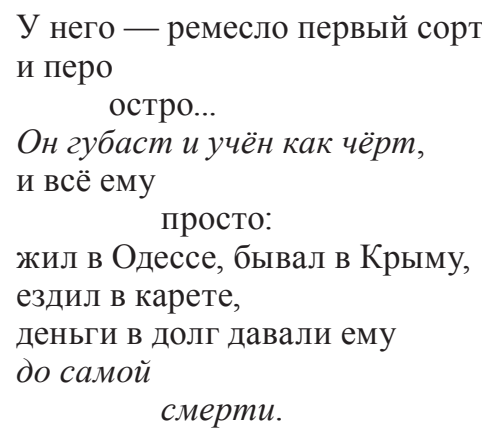

По мере развёртывания жизненного спектакля нарастают гротескные эффекты. Уподобление героя чёрту и сильная позиция слова смерть меняют буквальный смысл фразы об отношениях поэта с кредиторами: именно смертью счастливчика оказывается гарантирован возврат долга. Заново символизируя известный факт - посмертную уплату пушкинских долгов царём, Окуджава заставляет партнёров губастого чёрта послушно подыгрывать ему ради приближения «счастливого» финала. Так и подтверждается версия завистника Пушкина, что «всё шло ему на пользу» (Булгаков 1966: 48).

Представляя в качестве спутников жизни счастливчика людей государственных, Окуджава продолжает диалог с Булгаковым парафразом Последних дней: 


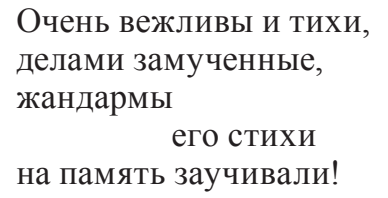

В четырёх стихах сжато содержание нескольких сцен пьесы с участием замученных делами жандармов. Император, заставший генерала Дубельта в рабочем кабинете поздно вечером, осведомляется: «Занимаешься? Не помешал ли я?»; затем сочувствует Бенкендорфу: «Прости, Александр Христофорович, что такую обузу тебе навязал. Истинное мучение!» (Булгаков 1965: 378, 380). Заучивание по долгу службы стихов Пушкина - сквозной мотив пьесы, рисующий бессильную попытку власти обуздать стихию. Дубельт выслушивает доклад осведомителя Биткова (обязанный запоминать дословно рукописи поднадзорного, тот декламирует «Буря мглою небо кроет...»); далее сам начальник корпуса жандармов невольно повторяет, раз за разом, загадочные строки о буре; в финале же Битков, отправленный присматривать за мёртвым Пушкиным по пути в Святые Горы, жалуется под вой метели: «Ах, сколько я стихов переучил, будь они неладны!» (Булгаков 1965: 373, 376, 382, 410). Таким образом, комплиментарная (в устах простодушного рассказчика) характеристика жандармов - очень вежливы и тихи - в действительности исполнена авторского сарказма, который проецируется и на «гостеприимного» царя:
Даже царь приглашал его в дом, желая при этом потрепаться о том о сём с таким поэтом.

Казалось бы, «ролевой» монолог чреват инвективой в духе булгаковской пьесы. Однако очередное усилительное даже придаёт пушкинскому «везению» прямо-таки сверхъестественный характер, а личные пристрастия счастливчика и обстоятельства его смерти сопрягаются по закону параллелизма:

\footnotetext{
Он красивых женщин любил любовью не чинной, и даже убит он был красивым мужчиной.
}

Финальная смена интонации придаёт новый смысл целому:

Он умел бумагу марать под треск свечки!

Ему было за что умирать у Чёрной речки.

(Окуджава 1967: 109-110) 
«Вольный» ритмический рисунок упорядочивается на последних восьми стихах, что даёт восходящее лирическое движение. Артистизм ведения речи обусловливает ту естественность, с которой «лёгкая» игра разрешается героическим аккордом.

В финале возникает единственная прямая отсылка к стихам счастливчика, воссоздающая пушкинскую самооценку. Уменье бумагу маpamb - реминисценция устойчивой формулы: «Я на брегу парнасских вод// Любил марать поэмы, оды...» (Пушкин 1956: 34); «Перу старинной нет охоты // Марать летучие листы...» (Пушкин 1957б: 137). Таким образом ретроспективно усложняется содержание «многоголосого» слова. Не сам ли Александр Сергеич уже в начале стихотворения насмешливо цитирует посмертные толки о себе? Пример герою Окуджавы подаёт Автор в Евгении Онегине: «Укажет будущий невежда//На мой прославленный портрет // И молвит: то-то был Поэт!» (Пушкин 1957б: 54).

Структурная сложность образа счастливчика, обусловленная памятью культуры о разных этапах земной и посмертной судьбы Пушкина, порождает развёрнутую метафору: даже «кривые толки, шум и брань» (Пушкин 1957б: 35) становятся достоянием героя стихотворения; воистину всё шло ему на пользу, всё обращалось к его славе.

\section{4. Интерпретация судьбы поэта: правдивость мифа}

Трансляция мифов о Пушкине-баловне и Пушкине-жертве оборачивается их ревизией, что не было для Окуджавы самоцелью. Его сверхзадача - целостная интерпретация судьбы поэта. Этапы движения лирической мысли отмечены неявными, имплицитными отсылками к пушкинскому миру. От начала и до конца, параллельно игровому диалогу с читателем, автор ведёт сокровенный диалог с самим Пушкиным: «Александру Сергеичу хорошо! //Ему прекрасно!//Гудит мельничное колесо,// боль угасла». Здесь подтекст маркирован деталью, памятной по 6-й главе Евгения Онегина, драме Русалка, элегии «Вновь я посетил...»: это мельница, которая в зрелом пушкинском творчестве устойчиво связана с темой смерти (Козмин 2004: 106-108). Реальная топография пушкинских мест получает символический смысл. Гудит мельничное колесо в окрестностях Михайловского - в деревне Бугрово, через которую пролегала дорога к ближней ярмарке у стен Святогорского монастыря6; и поскольку в свете финала угасшая боль означает смерть счастливчика, становится понятно, что речь идёт о месте погребения, которое Пушкин выбрал сам: «И хоть бесчувственному телу// Равно повсюду истлевать, //Но ближе к милому пределу //Мне всё б хотелось почивать» (Пушкин 1957a: 136). Именно здесь герою Окуджавы хоромо, пре-

6 Предположения о реальных впечатлениях автора «Счастливчика» см.: (Козмин 2013: 127-146). Датировка стихотворения, предложенная автором статьи, ошибочна. 
красно (так в очередной раз уточняется смысл ключевых слов, формирующих концепцию стихотворения). Всё сказанное позволяет выявить ассоциативные ходы, определившие прочтение пушкинских текстов.

Пафос победы над судьбой рождается в «Счастливчике» финальным соединением мотивов творчества и смерти. Конечно, этого ещё недостаточно для сопоставления с формулой бессмертия: «Нет, весь я не умру - душа в заветной лире// Мой прах переживёт и тленья убежит...» (Пушкин 1957a: 373). Но для Окуджавы, по-видимому, была ощутима связь между «Брожу ли я вдоль улиц шумных...» и «Памятником». Желание упокоиться ближе к милому пределу выражает диалектику отношений смертного человека с бессмертной жизнью, его «отчуждённостьпричастность»: «И пусть у гробового входа//Младая будет жизнь играть, // И равнодушная природа// Красою вечною сиять» (Пушкин 1957a: 136). В «Памятнике» «утверждается личное бессмертие, та духовная ипостась личности, которая выражена в слове»; декларация «Нет, весь я не умру..»» оспаривает прощальное слово Державина о всепожирающей вечности (Фомичёв 1990: 214-215). Но «Памятник» отвечает и на давнюю «думу» поэта о «грядущей смерти», сопровождавшую «день каждый, каждую годину» (Пушкин 1957a: 135). Оба «завещания» в контексте творчества Пушкина соотнесены.

То, что Пушкин сополагает, автор «Счастливчика» соединяет. В результате возникает неканонический образ вечной жизни: поэтическиусловное, метафорическое бессмертие (душа в заветной лире) словно бы материализуется, Александр Сергеич навсегда поселяется в родных местах. Весенняя картина («баба щурится из избы» от солнечного света, «в поле - жаворонки») напоминает о майском дне рождения Пушкина.

Вдохновлённый Булгаковым на парадоксальное заострение вопроса о смысле пушкинской судьбы, Окуджава совершенно иначе, чем автор Последних дней, осуществил мифологическое «возвращение домой». Путь булгаковского героя «в Святые Горы <..>, в обитель дальнюю» (Булгаков 1965: 410) — ночью, в метель - означает воссоединение с грозной потусторонней стихией, которой гений сродни (Яблоков 2001: 141). Напротив, герой Окуджавы земных земней; павший зимой у Чёрной реч$\kappa и$ (топоним несёт семантику ночи, мрака), он воскресает весной и обретает всё, что любил при жизни. Для выражения причастности бессмертного поэта к земному миру и нужны воспринимаемые его слухом звуки, увиденные вблизи детали, пространственные координаты Михайловского и Святых Гор. Важно, что в мире Окуджавы «возвращение поэта» (лирическая ситуация, объединяющая стихи о Пушкине, Грибоедове, Лермонтове) означает прохождение через смерть: именно такой ценой Пушкин возвышается над житейским опытом, взвешивает перипетии своей судьбы с точки зрения вечности - $и$ всё ему просто.

Подчеркнём ещё раз, что острое чувство трагедии сопровождало личное «открытие» Пушкина в зрелые годы Окуджавы. Сублимируя 
в творческом акте это переживание, поэт отнюдь его не смягчает. Пронзительное звучание последнего двустишия - «...умирать // у Чёрной речки» - усилено как фонетическими (ассонансы, аллитерации), так и композиционными средствами. Но именно через трагедию в последний раз заявляет о себе витальная творческая сущность героя: «Ему было за что умирать...». В гибельном поступке угадана свободная воля, «авторство» собственной судьбы. В целом поэтику стихотворения определяет свободный «перевод» пушкинских образов и мотивов на иной язык - при бережном отношении Окуджавы к ценностям пушкинского мира.

Пролагая собственный путь в пространстве мифов, Окуджава руководствовался отнюдь не буквальной «правдой факта». Главным ориентиром был тот смысл, который сам Пушкин хотел внести в свою жизнь. Если биографию Пушкина должно писать «как внутреннее психологическое единство, обусловленное единством личности, в том числе её воли, интеллекта, самосознания» (Лотман 2006: 346), то автор лирической интерпретации судьбы поэта правомочен символизировать жизненную стратегию своего героя; вопрос заключается в глубине творческой интуиции. Пушкинское «стремление не поддаваться обстоятельствам» (Лотман 2006: 347) - реальный источник условного образа счастливчика, властвующего и над словом, и над житейскими отношениями, и над смертью.

Адекватность этого образа личности Пушкина удостоверена Ю. М. Лотманом. Полемизируя с Б. Ф. Егоровым по поводу только что законченной книги, он апеллировал к стихотворению Окуджавы:

Вы поняли дело так, словно борьба и торжество в борьбе с обстоятельствами снимает трагичность <... . . Но бывают трагедии силы и трагедии слабости. Щёголев со товарищи много вреда наделали: следуя в русле либеральных штампов начала века, они создали миф «поэт и царь» и представили Пушкина замученным интеллигентом. Эти идеи прочно въелись, и все $<$... идут по этому лёгкому пути.

Между тем

...лучше всех Пушкина понял не исследователь, а поэт — Булат Окуджава. В его стихотворении «Александру Сергеичу хорошо, ему прекрасно...» больше понимания личности Пушкина, чем во многих академических трудах, и я полностью разделяю пафос его последних строк:

Ему было за что умирать у Чёрной речки...

Подводя итог, Ю. М. Лотман определил героя своей книги на языке Окуджавы: «Пушкин мне видится победителем, счастливием, а не мучеником» (Лотман 2006: 347-348). 


\section{ЛИТЕРАТУРА}

Абельская Раиса. Каждый пишет, как он сльшит. Поэтика Булата Окуджавы. Екатеринбург: Издательство УГТУ-УПИ, 2008.

Александрова Мария. «Ностальгия и зависть в лирике середины - второй половины ХХ века». Зависть. Формы её оправдания и разоблачения в культуре: [Материалы международной конференции. Пушкинские горы, 12-14 июля 2006 г.]. СанктПетербург: Пушкинский проект, 2007: 196-215.

Архипова Александра, Мельниченко Михаил. Анекдоты о Сталине. Тексты, комментарии, исследования. Москва: Издательство РГГУ, 2011.

Бахтин Михаил. Эстетика словесного творчества. Москва: Искусство, 1979.

Булат Окуджава. Специальный выпуск [Литературная газета]. 1997. [21 июля].

Булгаков Михаил. Драмы и комедии. Москва: Искусство, 1965.

Булгаков Михаил. «Мастер и Маргарита». Москва 11 (1966): 7-127.

Вдовин Алексей. «Годовщина смерти литератора как праздник: становление традиции в России (1850-1900-е гг.)». Alexander Graf (Hrsg.). Festkultur in der russischen Literatur (18. bis 21. Jahrhundert) - Культура праздника в русской литературе XVIIIXXI вв. München: UTZ, 2010: 81-93.

Гаспаров Борис. Литературные лейтмотивы. Очерки по русской литературе ХХ века. Москва: Наука; Издательская фирма «Восточная литература», 1993.

Евтушенко Евгений. Нежность. Москва: Советский писатель, 1962.

Загидуллина Марина. Пушкинский миф в конще XX века. Челябинск: Издательство Челябинского госуниверситета, 2001.

Захарченко Елена. «“Образ Пушкина” как феномен массового сознания». Пушкин и современная культура: [Материалы Междунар. науч. конф. 23-27 янв. 2003 г., Пушкинские горы]. Санкт-Петербург: Пушкинский проект, 2004: 146-155.

Кибальник Сергей. Пушкин и современная культура. Ленинград: Знание, 1989.

Козмин Вячеслав. «Мельница»//Н.И. Михайлова (ред.). Онегинская энииклопедия. В 2 т. T. II. Москва: Русский путь, 2004: 106-108.

Козмин Вячеслав. «С. С. Гейченко как соавтор Б. Ш. Окуджавы». Материаль XVI Февральских чтений памяти С. С. Гейченко «Хранители» (14-16 февраля 2013 года). Сельцо Михайловское: Пушкинский Заповедник, 2013: 127-146.

Кони Анатолий. Собрание сочинений. В 8 т. Т. 6. Москва: Издательство юридической литературы, 1968.

Лотман Юрий. Письма: 1940-1993. Москва: Языки славянской культуры, 2006.

Мусатов Владимир. Пушкинская традииия в русской поэзии первой половины ХХ века. Москва: Издательство РГГУ, 1998.

Новиков Владимир. «Дар и жертва в поэзии Булата Окуджавы, Владимира Высоцкого и Александра Галича». Grübel Rainer \& Kohler Gun-Britt (Hrsg.). Gabe und Opfer in der russischen Literatur und Kultur der Moderne (= Studia Slavica Oldenburgensia 13). Oldenburg: BIS-Verlag der Carl von Ossietzky Universitat Oldenburg, 2006: 465-477.

Окуджава Булат. «Он вошёл в нашу жизнь: в связи со 150-летием со дня гибели А. С. Пушкина: ответ на анкету». Наука и жизнь 2 (1987): 27-28.

Окуджава Булат. Март великодушный. Москва: Советский писатель, 1967.

Попович Таня. А. С. Пушкин в диалоге с другим. Большое Болдино; Нижний Новгород: Издательство Нижегородского госуниверситета, 2018.

Поповић Тања. Источни канон. Сремски Карловци; Нови Сад: Издавачка књижарница Зорана Стојановића, 2019.

Пушкин Александр. Полное собрание сочинений. В 10 т. Т. ІІ. Москва: Издательство АН CCCP, 1956.

Пушкин Александр. Полное собрание сочинений. В 10 т. Т. III. Москва: Издательство АН CCCP, 1957 (1957a).

Пушкин Александр. Полное собрание сочинений. В 10 т. Т. V. Москва: Издательство АН CCCP, 1957 (1957б). 
Сапгир Генрих. Черновики Пушкина, Буфарев и др. Москва: Раритет, 1992.

Секей Нина. «Пушкин в советской поэзии последних лет». Studia Slavica (Budapest) 17/1-2 (1971): 158-167.

Смеляков Ярослав. Избранные произведения. В 2 т. Т. 1. Москва: Художественная литература, 1967.

Фомичёв Сергей. «Памятник нерукотворный». Русская литература 4 (1990): 214-216.

Эпштейн Михаил. Парадоксы новизны: О литературном развитии XIX-XX веков. Москва: Советский писатель, 1988.

Яблоков Евгений. Художественный мир Михаила Булгакова. Москва: Языки славянской культуры, 2001.

\section{LITERATURE}

Abel'skaya Raisa. Kazhdyj pishet, kak on slyshit. Poetika Bulata Okudzhavy. Ekaterinburg: Izdatel'stvo UGTU-UPI, 2008.

Aleksandrova Mariya. «Nostal'giya i zavist' v lirike serediny — vtoroj poloviny XX veka». Zavist'. Formy eyo opravdaniya i razoblacheniya $v$ kul'ture: [Materialy mezhdunarodnoj konferencii. Pushkinskie gory, 12-14 iyulya 2006 g.]. Sankt-Peterburg: Pushkinskij proekt, 2007: 196-215.

Arhipova Aleksandra, Mel'nichenko Mihail. Anekdoty o Staline. Teksty, kommentarii, issledovaniya. Moskva: Izdatel'stvo RGGU, 2011.

Bahtin Mihail. Estetika slovesnogo tvorchestva. Moskva: Iskusstvo, 1979.

Bulat Okudzhava. Special'nyj vypusk [Literaturnaya gazeta]. 1997. [21 iyulya].

Bulgakov Mihail. Dramy i komedii. Moskva: Iskusstvo, 1965.

Bulgakov Mihail. «Master i Margarita». Moskva 11 (1966): 7-127.

Epshtejn Mihail. Paradoksy novizny: O literaturnom razvitii XIX-XX vekov. Moskva: Sovetskij pisatel', 1988.

Evtushenko Evgenij. Nezhnost'. Moskva: Sovetskij pisatel', 1962.

Fomichyov Sergej. «Pamyatnik nerukotvornyj». Russkaya literatura 4 (1990): 214-216.

Gasparov Boris. Literaturnye lejtmotivy. Ocherki po russkoj literature XX veka. Moskva: Nauka; Izdatel'skaya firma «Vostochnaya literatura», 1993.

Kibal'nik Sergej. Pushkin i sovremennaya kul'tura. Leningrad: Znanie, 1989.

Koni Anatolij. Sobranie sochineni.j V 8 t. T. 6. Moskva: Izdatel'stvo yuridicheskoj literatury, 1968.

Kozmin Vyacheslav. «Mel'nica»//N.I. Mihajlova (red.). Oneginskaya enciklopediya. V 2 t. T. II. Moskva: Russkij put', 2004: 106-108.

Kozmin Vyacheslav. "S. S. Gejchenko kak soavtor B. Sh. Okudzhavy». Materialy XVI Fevral'skih chtenij pamyati S. S. Gejchenko "Hraniteli» (14-16 fevralya 2013 goda). Sel'co Mihajlovskoe: Pushkinskij Zapovednik, 2013: 127-146.

Lotman Yurij. Pis'ma: 1940-1993. Moskva: Yazyki slavyanskoj kul'tury, 2006.

Musatov Vladimir. Pushkinskaya tradiciya v russkoj poezii pervoj poloviny XX veka. Moskva: Izdatel'stvo RGGU, 1998.

Novikov Vladimir. «Dar i zhertva v poezii Bulata Okudzhavy, Vladimira Vysockogo i Aleksandra Galicha». Grübel Rainer \& Kohler Gun-Britt (Hrsg.). Gabe und Opfer in der russischen Literatur und Kultur der Moderne (= Studia Slavica Oldenburgensia 13). Oldenburg: BIS-Verlag der Carl von Ossietzky Universitat Oldenburg, 2006: 465-477.

Okudzhava Bulat. "On voshyol v nashu zhizn': v svyazi so 150 -letiem so dnya gibeli A. S. Pushkina: otvet na anketu». Nauka i zhizn' 2 (1987): 27-28.

Okudzhava Bulat. Mart velikodushnyj. Moskva: Sovetskij pisatel', 1967.

Popovich Tanya. A. S. Pushkin v dialoge s drugim. Bol'shoe Boldino; Nizhnij Novgorod: Izdatel'stvo Nizhegorodskogo gosuniversiteta, 2018.

Popović Tanja. Istočni kanon. Sremski Karlovci; Novi Sad: Izdavačka knjižarnica Zorana Stojanovića, 2019. 
Pushkin Aleksandr. Polnoe sobranie sochinenij. V 10 t. T. II. Moskva: Izdatel'stvo AN SSSR, 1956.

Pushkin Aleksandr. Polnoe sobranie sochinenij. V 10 t. T. III. Moskva: Izdatel'stvo AN SSSR, 1957 (1957a).

Pushkin Aleksandr. Polnoe sobranie sochinenij. V 10 t. T. V. Moskva: Izdatel'stvo AN SSSR, 1957 (1957b).

Sapgir Genrih. Chernoviki Pushkina, Bufarev i dr. Moskva: Raritet, 1992.

Sekej Nina. «Pushkin v sovetskoj poezii poslednih let». Studia Slavica (Budapest) 17/1-2 (1971): 158-167.

Smelyakov Yaroslav. Izbrannye proizvedeniya. V 2 t. T. 1. Moskva: Hudozhestvennaya literatura, 1967.

Vdovin Aleksej. «Godovshchina smerti literatora kak prazdnik: stanovlenie tradicii v Rossii (1850-1900-e gg.)». Alexander Graf (Hrsg.). Festkultur in der russischen Literatur (18. bis 21. Jahrhundert) - Kul'tura prazdnika v russkoj literature XVIII-XXI vv. München: UTZ, 2010: 81-93.

Yablokov Evgenij. Hudozhestvennyj mir Mihaila Bulgakova. Moskva: Yazyki slavyanskoj kul'tury, 2001.

Zagidullina Marina. Pushkinskij mif v konce XX veka. Chelyabinsk: Izdatel'stvo Chelyabinskogo gosuniversiteta, 2001.

Zaharchenko Elena. «"Obraz Pushkina” kak fenomen massovogo soznaniya». Pushkin i sovremennaya kul'tura: [Materialy Mezhdunar. nauch. konf. 23-27 yanv. 2003 g., Pushkinskie gory]. Sankt-Peterburg: Pushkinskij proekt, 2004: 146-155.

\section{Марија Александрова}

\section{МИТОВИ О ПУШКИНУ И ПЕСМА БУЛАТА ОКУЏАВЕ „СРЕЋНИК“}

\section{Резиме}

Песма Булата Окуџаве се разматра у светлу општеприхваћених законитости, које одређују стварање лика великог песника, на фону главних тенденција митологизације Пушкина у књижевности совјетске епохе, у контексту различитих представа о песничком дару. Приликом реконструкције историје стварања „Срећника“ посебна пажња је посвећена рецепцији пушкинијане Булгакова. Приказана је међусобна веза говорне композиције песме и структуре лика срећника. Целовита интерпретација судбине Пушкина у песми Окуџаве осмишљена је као лирски мит, чију истинитост је веродостојно оценио Ј. Лотман.

Кључне речи: Пушкин, Окуџава, Булгаков, мит, дијалог, подтекст. 